\title{
Penerimaan Ibu yang Memiliki Anak Retardasi Mental di SLB YPAC Padang
}

\author{
Faraznasia Benny, Adnil Edwin Nurdin, Eva Chundrayetti
}

\begin{abstract}
Abstrak
Penerimaan merupakan sikap seseorang yang menerima orang lain apa adanya secara keseluruhan, tanpa disertai persyaratan ataupun penilaian. Apabila dalam keluarga terutama pada ibu ada penerimaan, maka dapat membantu dalam pengasuhan dan akan mendukung perkembangan anak. Namun tidak mudah bagi seorang ibu untuk dapat menerima begitu saja kondisi anaknya.Penelitian ini bertujuan untuk memperoleh gambaran penerimaan ibu terhadap anaknya yang mengalami gangguan retardasi mental, faktor-faktor yang menyebabkan penerimaan serta gambaran retardasi mental secara pendekatan kualitatif dalam bentuk eksplorasi. Subyek penelitian ini adalah tiga orang ibu yang memiliki anak yang mengalami gangguan retardasi mental. Dalam penelitian ini digunakan teknik wawancara semi terstruktur. Berdasarkan hasil penelitian secara umum, satu dari tiga orang subyek penelitian dapat dikatakan telah menerima anaknya dengan baik, hal ini terlihat dari sikap subyek yang telah memenuhi keseluruhan aspek penerimaan ibu terhadap anak yaitu kecemasan yang minimal terhadap kehadiran anak, pembelaan diri yang minimal atas keterbatasan anak, dan tidak adanya penolakan. Disamping itu kedua subyek tersebut juga memperlihatkan adanya kontrol terhadap perkembangan anak, memberikan tekanan atas kemampuan anak, komunikasi yang hangat, pengasuhan yang baik, adanya sikap menghargai dan penlaian yang positif terhadap anak, juga pengenalan atas kebutuhan anak dalam pengembangan kemandirian anak. Namun pada dasarnya seluruh subyek dapat memenuhi aspek yang terkait dengan pengasuhan, dan tidak adanya penolakan yang terlihat dari ibu. Gambaran retardasi mental yang dialami anak subyek dapat dikatakan terlihat jelas dari bentuk fisik. Kondisi keterbelakangan mental anak dari subyek $A, B$, dan $C$ terlihat tidak terlalu parah. Faktor yang paling menonjol dalam penerimaan dari ketiga subyek adalah faktor agama, dimana seluruh subyek menyatakan dapat menerima kondisi anak setelah menyerahkan seluruhnya kepada Tuhan.
\end{abstract}

Kata kunci: Penerimaan Ibu, Retardasi Mental, Anak

\begin{abstract}
The acceptance is an attitude of someone who accepts other people as they are as they are whole, without any requirements or assessment. When a family, especially the mother has reception, then it can assist in education and support the development of children. But it is not easy for a mother to be able to take for granted of her child condition. The aim of this study was to obtain an acceptance overview of the mother whose children suffered mental retardation disorder, the factors led to the acceptance as well as an overview of mental retardation by a qualitative approach in the form of exploration. The subjects were three mothers whose children with mental retardation disorders. This study used semi-structured interview techniques. Based on the results of general research, two of the three research subjects can be said that they have accepted their children well, as seen from the attitude of the subject who has fulfilled all aspects of the mothers' acceptance to their children are the minimal anxiety to the presence of the children, a minimal self-defense about the limitations of the children, and the absence of rejection. Besides, these two subjects also showed that the control of the development of the children, pressure giving on the children's ability, warm communication, good parenting, respection and a positive judgement against children, also a recognition of the children's needs in the development of the children's independence. But basically the whole subject can fulfill aspects associated with caregiving, and the absence of a rejection seen on the mother. The overview of mental retardation suffered by the subject children can be said is obvious from the physical form. Mental retardation of the childrens' condition subjects $A, B$, and $C$ are not too severe. The most prominent factor in the acceptance of the three subjects is the religion factor, where the whole subjects state can accept the childrens' condition after the completely submission to the God.
\end{abstract}

Keywords:Mother Acceptance, Mental Retardation, Children

Affiliasi penulis : Fakultas Kedokteran Universitas Andalas Korespondensi :Faraznasia Benny, Email: farazzu@yahoo.co.id, Telp: 085274047010

\section{PENDAHULUAN}

Memiliki anak dengan gangguan intelegensi merupakan salah satu hal yang berada diluar konsep anak idaman dari setiap pasangan suami istri. Anakanak yang memiliki keterbelakangan mental ini sering mengalami kesukaran dalam mengikuti pendidikan selayaknya anak normal dan juga memiliki kesulitan dalam mengurus diri sendiri dalam masyarakat, sehingga dalam melakukan berbagai aktivitas ia harus dibantu oleh orang lain. Hal ini mengakibatkan anak- anak tersebut memiliki rasa ketergantungan yang sangat tinggi.

Salah satu gangguan inteligensi yang banyak terjadi disekitar kita adalah gangguan retardasi mental. Retardasi mental tergolong gangguan Aksis II yang didefinisikan dalam Diagnostic and Statistical Manual of Mental Disorders, 4th Edition, Text Revision (DSMIV-TR) sebagai fungsi intelektual yang sangat dibawah rata-rata, kurangnya prilaku adaptif, dan terjadi sebelum usia 18 tahun. $^{2}$

Retardasi mental dapat diklasifikasikan menjadi retardasi mental ringan dengan IQ 50-55 hingga 70, retardasi mental sedang dengan IQ 35-40 hingga 50-55, retardasi mental berat dengan IQ 20-25 
hingga $35-40$, retardasi mental sangat berat dengan IQ di bawah 25 . $^{2}$

Hasil studi Bank Dunia menunjukkan, Global Burden of Disease akibat masalah kesehatan mental mencapai 8,1\%. Menurut World Health Organization (WHO) tahun 2001, berdasarkan standar skor dari kecerdasan kategori American Association of Mental Retardation (AAMR) gangguan mental manual klasifikasi penyakit menempati urutan kesepuluh di dunia. Prevalensi penduduk di Indonesia yang mengalami retardasi mental menurut data semua provinsi yang ada di Indonesia dan jenis kecacatannya pada tahun 2000 adalah 189.625 orang atau $12,72 \%$.

Berdasarkan data yang diperoleh dari Dinas Sosial Provinsi Sumatera Barat Tahun $2009,{ }^{4}$ tercatat 10.390 orang cacat mental, yang terdiri dari 5.872 orang retardasi mental, 2.031 orang eks psikotik dan 2.487 orang cacat mental ganda, di kota Padang tercatat sebanyak 2.084 orang yang cacat mental, yang terdiri dari 797 orang retardasi mental, 270 eks psikotik, dan 1.017 cacat mental ganda. Menurut data yang diperoleh dari Dinas Pendidikan Pemuda dan Olah Raga, pada tahun $2011^{5}$ tercatat penderita cacat mental yang menerima pendidikan di Sekolah Luar Biasa (SLB) di Sumatera Barat sebanyak 4.655 orang yang tersebar di 109 SLB dan di kota Padang tercatat sebanyak 1.347 orang yang menerima pendidikan di 34 SLB.

Tingginya angka kejadian retardasi mental tentu tidak bisa dibiarkan begitu saja, anak - anak tersebut harus mendapat pendidikan yang baik terutama dari keluarganya sehingga mereka lebih mandiri, minimal untuk aktivitas sehari - hari. Namun pada kenyataannya tidak semua keluarga yang dapat menerima kondisi kelainan yang dialami anaknya. Individu yang dapat menerima dirinya dengan baik, akan dengan mudah menyesuaikan diri dengan lingkungannya. Individu yang tidak dapat menerima dirinya akan mengalami frustasi yang menjadikan individu merasa tidak berdaya dan gagal sehingga tingkat penyesuaian dirinya buruk. Hal ini berhubungan dengan konsep harga diri orang tua. Harga diri merupakan penilaian individu terhadap diri sendiri bertolak dari persepsinya terhadap penilaian lingkungan eksternal pada dirinya. ${ }^{6}$

Tujuan penelitian ini adalah untuk mengetahui bentuk penerimaan ibu yang memiliki anak retardasi mental di SLB YPAC Padang dan faktor-faktor yang melatarbelakangi penerimaan pada ibu yang memiliki anak retardasi mental.

\section{METODE}

Penelitian ini menggunakan pendekatan analisis kualitatif dan menggunakan rancangan deskriptif. Penelitian ini berusaha menggambarkan situasi atau kejadian. Data yang dikumpulkan sematamata bersifat deskriptif sehingga tidak bermaksud mencari penjelasan, menguji hipotesis, membuat

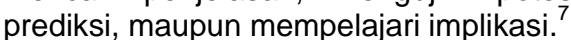

Penelitian ini akan dilakukan di Sekolah Luar Biasa Yayasan Pembinaan Anak Cacat (SLB YPAC) jalan Bakti II no. 14 Kelurahan Parak Kopi, Padang. Penelitian dilakukan mulai bulan November 2011 sampai Agustus 2013

Populasi penelitian adalah ibu kandung dari siswa SLB YPAC Padang yang menderita retardasi mental. Dalam penelitian kualitatif tidak ada sampel acak tetapi sampel bertujuan (purposive sample)yaitu pengambilan sampel atau subyek disesuaikan dengan keadaan atau tipikal khusus yang sedang diteliti, dengan kriteria subyek penelitian 1) ibu yang memiliki anak yang mengalami retardasi mental, 2) bersedia untuk menjadi sampel penelitian ini.

Peneliti adalah instrumen itu sendiri pada penelitian kualitatif yang dibantu dengan guide interview. Guide interview dibuat berdasarkan teori penerimaan ibu terhadap anak dari Porter $^{8}$, Zuck. $^{8}$

Data yang digunakan adalah data primer yang diperoleh dari hasil observasi dan wawancara langsung dengan menggunakan guideinterview terhadap subyek penelitian yaitu ibu dan guru sebagai subyek pendukung.

Bogdan dan Biklen ${ }^{9}$ menyatakan bahwa analisis data kualitatif adalah upaya yang dilakukan dengan jalan bekerja dengan data, mengorganisasikan data, memilah-milahnya menjadi satuan yang dapat di kelola, mensintesiskannya, mencari dan menemukan pola, menemukan apa yang penting dan apa yang dipelajari dan memutuskan apa yang dapat diceritakan kepada orang lain.

\section{HASIL}

Peneliti melakukan wawancara dan observasi serta pengumpulan data dari bulan Maret 2013 sampai April 2013. Peneliti melakukan building rapport dengan kepala sekolah dan guru yang mengajar mulai dari bulan Maret, dimana peneliti mendapatkan informasi bahwa terdapat 3 orang siswa dengan gangguan retardasi mental yang sesuai dengan kriteria dan memiliki kondisi yang khas dari masing-masing keluarga. Peneliti juga dibantu untuk melakukan observasi awal dan pendekatan terhadap siswa tersebut. Sedangkan waktu yang efektif dalam pengambilan data pada penelitian ini adalah 2 (dua) bulan

Jadwal pertemuan peneliti dengan subyek adalah sebagai berikut:

Tabel 1.Pertemuan dengan Subyek A dan keyperson1

\begin{tabular}{|c|c|c|c|c|c|}
\hline No. & Tanggal & Jam & Tempat & Kegiatan & $\begin{array}{l}\text { Catatan } \\
\text { kemajuan }\end{array}$ \\
\hline 1. & $\begin{array}{l}7 \quad \text { Maret } \\
2013\end{array}$ & $\begin{array}{l}09.00- \\
12.00\end{array}$ & Sekolah & Observasi & \begin{tabular}{l}
\multicolumn{2}{l}{ Pertemuan } \\
dengan kepala \\
sekolah dan guru \\
YPAC; \\
menjelaskan \\
tujuan penelitian \\
dan kriteria \\
subyek yang \\
diinginkan; \\
observasi \\
langsung di kelas
\end{tabular} \\
\hline 2. & $\begin{array}{l}8 \quad \text { Maret } \\
2013\end{array}$ & $\begin{array}{l}10.00- \\
11.30\end{array}$ & Sekolah & Observasi & $\begin{array}{l}\text { Observasi di } \\
\text { kelas; meminta } \\
\text { hasil tes IQ anak } \\
\text { subyek yang ada } \\
\text { di data YPAC; } \\
\text { pendekatan } \\
\text { kepada anak } \\
\text { subyek dan } \\
\text { mencari tahu } \\
\text { rumah subyek }\end{array}$ \\
\hline 3. & $\begin{array}{l}20 \text { Maret } \\
2013\end{array}$ & $\begin{array}{l}12.00- \\
13.00\end{array}$ & $\begin{array}{l}\text { Rumah } \\
\text { Subyek }\end{array}$ & $\begin{array}{l}\text { Observasi } \\
\text { dan } \\
\text { wawancara } \\
\text { awal }\end{array}$ & $\begin{array}{l}\text { Pendekatan } \\
\text { dengan subyek } \\
\text { dan keluarga; } \\
\text { observasi di mohon } \\
\text { rumah; mi } \\
\text { izin penelitian }\end{array}$ \\
\hline 4. & $\begin{array}{l}21 \text { Maret } \\
2013\end{array}$ & $\begin{array}{l}10.00- \\
10.30\end{array}$ & Sekolah & $\begin{array}{l}\text { Wawancara } \\
\text { dengan KP } \\
1\end{array}$ & $\begin{array}{lr}\text { Mencari informasi } \\
\text { yang diperlukan } \\
\text { sesuai } \text { dengan } \\
\text { guide interview } \\
\text { KP }\end{array}$ \\
\hline 5. & $\begin{array}{l}21 \text { Maret } \\
2013\end{array}$ & $\begin{array}{l}14.00- \\
15.00\end{array}$ & $\begin{array}{l}\text { Rumah } \\
\text { Subyek }\end{array}$ & $\begin{array}{l}\text { Wawancara } \\
\text { dan } \\
\text { observasi }\end{array}$ & $\begin{array}{l}\text { Mencari informasi } \\
\text { yang diperlukan } \\
\text { sesuai guide } \\
\text { interview }\end{array}$ \\
\hline
\end{tabular}


Tabel 2.Pertemuan dengan Subyek B dan keyperson2

\begin{tabular}{|c|c|c|c|c|c|}
\hline No. & Tanggal & Jam & Tempat & Kegiatan & Catatan kemajuan \\
\hline 1. & $\begin{array}{l}7 \quad \text { Maret } \\
2013\end{array}$ & $\begin{array}{l}09.00- \\
12.00\end{array}$ & Sekolah & Observasi & $\begin{array}{l}\text { Pertemuan dengan } \\
\text { kepala sekolah dan } \\
\text { guru YPAC; } \\
\text { menjelaskan tujuan } \\
\text { penelitian dan } \\
\text { kriteria subyek } \\
\text { yang dinginkan; } \\
\text { observasi langsung } \\
\text { di kelas }\end{array}$ \\
\hline 2. & $\begin{array}{l}8 \text { Maret } \\
2013\end{array}$ & $\begin{array}{l}10.00- \\
11.30\end{array}$ & Sekolah & Observasi & $\begin{array}{lr}\text { Observasi di } & \text { kelas; } \\
\text { pendekatan } & \\
\text { kepada } & \text { anak } \\
\text { subyek } & \text { dan } \\
\text { mencari } & \text { tahu } \\
\text { rumah subyek } & \end{array}$ \\
\hline 3. & $\begin{array}{l}14 \text { Maret } \\
2013\end{array}$ & $\begin{array}{l}16.30- \\
17.00\end{array}$ & $\begin{array}{l}\text { Rumah } \\
\text { Subyek }\end{array}$ & $\begin{array}{l}\text { Observasi } \\
\text { dan } \\
\text { wawancara } \\
\text { awal }\end{array}$ & 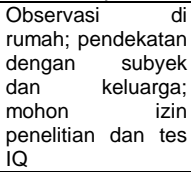 \\
\hline 4. & $\begin{array}{l}14 \text { Maret } \\
2013\end{array}$ & $\begin{array}{l}17.00- \\
18.00\end{array}$ & $\begin{array}{l}\text { RS Puti } \\
\text { Bungsu }\end{array}$ & $\begin{array}{l}\text { Observasi } \\
\text { dan Tes IQ }\end{array}$ & $\begin{array}{l}\text { Observasi selama } \\
\text { tes IQ; tes IQ } \\
\text { dengan psikolog }\end{array}$ \\
\hline 5. & $\begin{array}{l}21 \text { Maret } \\
2013\end{array}$ & $\begin{array}{l}15.30- \\
16.30\end{array}$ & $\begin{array}{l}\text { Rumah } \\
\text { Subyek }\end{array}$ & $\begin{array}{l}\text { Wawancara } \\
\text { dan } \\
\text { observasi }\end{array}$ & $\begin{array}{lr}\text { Mencari } & \text { informasi } \\
\text { yang } & \text { diperlukan } \\
\text { sesuai } & \text { guide } \\
\text { interview } & \\
\end{array}$ \\
\hline 6. & $\begin{array}{l}16 \\
2013\end{array}$ April & $\begin{array}{l}10.00- \\
10.20\end{array}$ & Sekolah & $\begin{array}{l}\text { Wawancara } \\
\text { dengan KP } 2\end{array}$ & $\begin{array}{lr}\text { Mencari } & \text { informasi } \\
\text { yang diperlukan } \\
\text { sesuai } & \text { dengan } \\
\text { guide interview KP }\end{array}$ \\
\hline
\end{tabular}

Tabel 3.Pertemuan dengan Subyek $\mathrm{C}$ dan keyperson3

\begin{tabular}{|c|c|c|c|c|c|}
\hline No. & Tanggal & Jam & Tempat & Kegiatan & Catatan kemajuan \\
\hline 1. & $\begin{array}{l}7013 \\
\text { Maret }\end{array}$ & $\begin{array}{l}09.00- \\
12.00\end{array}$ & Sekolah & Observasi & $\begin{array}{lr}\text { Pertemuan dengan } \\
\text { kepala sekolah dan } \\
\text { guru YPAC; } \\
\text { menjelaskan tujuan } \\
\text { penelitian dan } \\
\text { kriteria subyek } \\
\text { yang dinginkan; } \\
\text { observasi langsung } \\
\text { di kelas }\end{array}$ \\
\hline 2. & $\begin{array}{l}8 \text { Maret } \\
2013\end{array}$ & $\begin{array}{l}10.00- \\
11.30\end{array}$ & Sekolah & Observasi & $\begin{array}{lr}\text { Observasi di } & \text { kelas; } \\
\text { pendekatan } & \\
\text { kepada } & \text { anak } \\
\text { subyek dan } & \text { mencari tahu } \\
\text { rumah subyek } & \\
\end{array}$ \\
\hline 3. & $\begin{array}{l}21 \text { Maret } \\
2013\end{array}$ & $\begin{array}{l}10.30- \\
11.00\end{array}$ & Sekolah & $\begin{array}{l}\text { Wawancara } \\
\text { dengan KP } 3\end{array}$ & $\begin{array}{lr}\text { Mencari informasi } \\
\text { yang diperlukan } \\
\text { sesuai dengan } \\
\text { guide interview KP }\end{array}$ \\
\hline 3. & $\begin{array}{l}21 \text { Maret } \\
2013\end{array}$ & $\begin{array}{l}12.00- \\
13.00\end{array}$ & $\begin{array}{l}\text { Rumah } \\
\text { Subyek }\end{array}$ & $\begin{array}{l}\text { Observasi } \\
\text { dan } \\
\text { wawancara } \\
\text { awal }\end{array}$ & 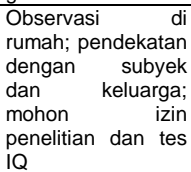 \\
\hline 4. & $\begin{array}{l}22 \text { Maret } \\
2013\end{array}$ & $\begin{array}{l}17.00- \\
18.00\end{array}$ & $\begin{array}{l}\text { RS Puti } \\
\text { Bungsu }\end{array}$ & $\begin{array}{l}\text { Observasi } \\
\text { dan Tes IQ }\end{array}$ & $\begin{array}{l}\text { Observasi selama } \\
\text { tes IQ; tes IQ } \\
\text { dengan psikolog }\end{array}$ \\
\hline 5. & $\begin{array}{l}24 \text { Maret } \\
2013\end{array}$ & $\begin{array}{l}19.50- \\
20.30\end{array}$ & $\begin{array}{l}\text { Rumah } \\
\text { Subyek }\end{array}$ & $\begin{array}{l}\text { Wawancara } \\
\text { dan } \\
\text { observasi }\end{array}$ & $\begin{array}{lr}\text { Mencari } & \text { informasi } \\
\text { yang } & \text { diperlukan } \\
\text { sesuai } & \text { guide } \\
\text { interview } & \\
\end{array}$ \\
\hline
\end{tabular}

Adapun tahap-tahap yang dilakukan dalam penelitian:

a. Menjalin good rapport dengan subyek dan keluarga.

b. Meminta kesedian subyek untuk menjadi subyek penelitian ini bersama anaknya.

c. Melakukan wawancara dan observasi terhadap subyek, anak subyek yang terkena retardasi mental, dan key person (guru yang mengajar anak subyek).

d. Membuat catatan lapangan atau logbook setiap sesudah pengambilan data.

e. Membuat verbatim wawancara

f. Membuat laporan penelitian.

\section{PEMBAHASAN}

Tabel 4. Aspek penerimaan ibu yang dipelihatkan oleh subyek

\begin{tabular}{|c|c|c|c|}
\hline Subyek & A & B & C \\
\hline $\begin{array}{l}\text { Kecemasan yang minimal } \\
\text { terhadap kehadiran anak }\end{array}$ & $\sqrt{ }$ & $x$ & $x$ \\
\hline $\begin{array}{l}\text { Pembelaan diri yang minimal } \\
\text { terhadap keterbatasan anak }\end{array}$ & $\sqrt{ }$ & $x$ & $\sqrt{ }$ \\
\hline $\begin{array}{l}\text { Tidak ada } \\
\text { Indikasi menolak anak }\end{array}$ & $\sqrt{ }$ & $\sqrt{ }$ & $\sqrt{ }$ \\
\hline $\begin{array}{l}\text { Kontrol terhadap perkembangan } \\
\text { anak }\end{array}$ & $\sqrt{ }$ & $\mathrm{x}$ & $\sqrt{ }$ \\
\hline Tuntutan kematangan pada anak & $\sqrt{ }$ & $\mathrm{X}$ & $\sqrt{ }$ \\
\hline $\begin{array}{l}\text { Komunikasi yang jelas } \\
\text { antara ibu dan anak }\end{array}$ & $\sqrt{ }$ & $\checkmark$ & $\sqrt{ }$ \\
\hline Pegasuhan ibu terhadap anak & $\sqrt{ }$ & $\sqrt{ }$ & $\sqrt{ }$ \\
\hline Sikap menghargai dari ibu & $\sqrt{ }$ & $\sqrt{ }$ & $\sqrt{ }$ \\
\hline $\begin{array}{l}\text { Penilaian ibu terhadap kekurangan } \\
\text { anak }\end{array}$ & $\sqrt{ }$ & $\sqrt{ }$ & $\checkmark$ \\
\hline $\begin{array}{c}\text { Mengenal kebutuhan anak agar } \\
\text { mandiri }\end{array}$ & $\sqrt{ }$ & $x$ & $\sqrt{ }$ \\
\hline
\end{tabular}

Berdasarkan tabel di atas dapat disimpulkan bahwa dari tiga orang subyek dalam penelitian ini hanya 1 orang subyek yang memenuhi seluruh aspek dalam penerimaannya terhadap anak dengan gangguan retardasimental yaitu subyek $A$. Namun jika dilihat secara keseluruhan, ketiga subyek tersebut, tidak memperlihatkan indikasi penolakan terhadap anak, disamping itu, ketiga subyek terlihat memiliki perhatian dan cinta yang besar terhadap anaknya, hal ini diperkuat dengan pernyataan dari masing-masing key person.

Berdasarkan hasil interview yang peneliti lakukan, peneliti menemukan bahwa faktor terbesar yang melatarbelakangi penerimaan ibu adalah faktor agama, seperti yang disampaikan oleh DarlingDarling $^{8}$ bahwa salah satu faktor penerimaan ibu terhadap keterbatasan anak adalah agama, dimana orang tua yang lebih intens dalam melakukan praktek agama cenderung bersikap lebih menerima anak-anak mereka yang terhambat secara fisik. Dalam hal ini dapat dilihat bahwa seluruh subyek dalam penelitian ini memiliki penghargaan yang tinggi terhadap agama.

\section{KESIMPULAN}

1. Berdasarkan hasil observasi dan wawancara, diketahui bahwa anak dari ketiga subyek mengalami gangguan retardasi mental yang berada pada level sedang. Gangguan retardasi mental yang dialami oleh anak subyek dapat dikenali dari bentuk fisik yang terlihat jelas memenuhi karakteristik atau ciriciri anak retardasi mental. Kemampuan motorik kasar pada anak ketiga subyek terlihat berkembang cukup baik, namun kemampuan motorik halus yang berkembang dengan cukup baik hanya terlihat pada anak subyek $A$ dan $C$. Pada umumnya anak dari ketiga subyek cukup mandiri dalam hal tertentu. Namun kemandirian dalam mengurus keperluan pribadi dan kebersihan hanya terlihat pada anak dari subyek $A$ dan C. Anak dari subyek A, B, C terlihat mampu memahami instruksi sederhana.

2. Dari ketiga subyek dalam penelitian ini, hanya satu yang memiliki sikap menerima 
terhadap gangguan retardasi mental yang dialami oleh anaknya. Hal ini ditunjukkan dengan terpenuhinya kesepuluh aspek penerimaan ibu terhadap anak. Berdasarkan keterangan yang diperoleh dari ketiga subyek dalam penelitian ini, terdapat dua orang subyek yang terlihat belum dapat menerima anak dengan seutuhnya, dimana hanya terdapat sembilan dan lima aspek yang terpenuhi.

3. Faktor yang paling menonjol melatarbelakangi penerimaan ibu adalah faktor agama, dari ketiga subyek, peneliti menemukan bahwa saat ini mereka memiliki penilaian bahwa anak dengan retardas mental adalah ciptaan Tuhan yang memiliki hak yang sama dengan anak normal lainnya. Disamping itu terdapat beberapa faktor lainnya yang juga turut mempengaruhi penerimaan ibu yaitu, respon anak terhadap ibu,

\section{DAFTAR PUSTAKA}

1. Somantri S. Psikologi anak luar biasa. Bandung: Rafika Aditama; 2007.

2. Davison, Gerald C, John M. Neale, Ann M K. Psikologi abnormal. Jakarta: PT. Raja Grafindo Persada; 2006.

3. Darwis. hubungan peran orang tua dengan tingkat kemandirian anak retardasi mental usia 10-14 tahun di SDLB Prof. DR. Sri Soedewi Masjchun Sofwan, SH Kota Jambi. (skripsi). Jambi: Akper Telanai Bhakti Jambi; 2010.

4. Dinas Sosial Provinsi Sumatera Barat. Rekapitulasi data penyandang cacat. Padang: Dinsos Sumbar; 2009.

5. Dinas Pendidikan Pemuda dan Olah Raga Provinsi Sumatera Barat. Surat keputusan tentang nama-nama sekolah penerima bantuan beasiswa pendidikan khusus dan pendidikan layanan khusus provinsi Sumbar tahun 2011. Padang: Dispenpora Sumbar; 2011

6. Nurdin AE. Buku ajar ilmu perilaku kedokteran: tumbuh kembang perilaku manusia. Jakarta: EGC; 2010.

7. Azwar S. Metode penelitian, Jakarta: Pustaka Pelajar; 2007.

8. Ningrum DP. Pengaruh penerimaan orang tua terhadap penyesuaian diri anak tuna rungu di sekolah tahun ajaran $2006-2007$ (penelitian pada Slb "B" Widya Bhakti Semarang dan Slb "B" Yrtrw Surakarta) (skripsi). Semarang: Fakultas IImu Pendidikan Universitas Negeri Semarang; 2007.

9. Moleong LJ. Metodologi penelitian kualitatif. Edisi Revisi. Bandung: PT. Remaja Rosda karya; 2008. 